\title{
PLAYING GOD: THE LANDSCAPE OF RESURRECTION IN ROMEO AND JULIET
}

And he that was dead came forth, bound hand $\mathcal{E}$ foot with graue-clothes: and his face was bound about with a napkin. *

\section{Shakespeare's Deathscapes}

$\mathrm{U}$ ntil recently, landscape studies in early modern scholarship have been primarily confined to issues of land ownership and economics, ${ }^{1}$ or with the dichotomy between urban and pastoral representations of the natural and built environments in literature. ${ }^{2}$ However, despite differing approaches it is clearly apparent that critics and scholars all come to a universal consensus: land and landscapes have meaning beyond a reductive idea of a locality in nature or functional purpose and can be read culturally, historically, and socially as texts. Denis Cosgrove's analysis supports this claim, in which he states that "landscape denotes the external world mediated through subjective human experience in a way that neither region nor area immediately suggest". ${ }^{3}$ In this way, Cosgrove argues, we can examine large issues shared by multiple cultures and societies through the lens of landscape. Therefore, using Lily Kong's notion of "deathscapes", 4 or those landscapes explicitly defined by their

*. John 11:44. All Bible quotes come from the 1611 version of the King James Bible.

1. See, for example, Garrett Sullivan's The Drama of Landscape: Land, Property, and Social Relations on the Early Modern Stage (Stanford: Stanford University Press, 1998), Denis Cosgrove's Social Formation and Symbolic Landscape (Madison: University of Wisconsin Press, 1998), David Harvey, Justice, Nature, and the Geography of Difference (Malden, MA: Blackwell Publishing, 1996).

2. See, for example Gerald MacLean, Donna Landry, and Joseph P. Ward, The Country and the City Revisited: England and the Politics of Culture, 1550-1850 (Cambridge: University of Cambridge Press, 1999).

3. Denis Cosgrove, Social Formation and Symbolic Landscape, 13.

4. Lily Kong, "Cemeteries and Columbaria, Memorials and Mausoleums: Narrative and Interpretation in the Study of Deathscapes in Geography", Australian Geographical Studies. 37:1 (March, 1999), 1-10, 1. relationships with cultural elements of death graveyards, crypts, churches, etc. - I plan to explore the cultural significance of these landscapes as they pertain to the concepts of transgression and resurrection in Shakespeare's Romeo and Juliet.

Specifically, I argue that when Shakespeare's characters attempt to recreate the miracle of resurrection upon those spaces scripted solely for the dead, they are punished not only for their inability to recognize the culturally acceptable meanings of the deathscapes but they also mirror Satan's deadly sin of Pride ${ }^{5}$ by taking upon themselves the power of resurrection, a form of miracle meant for divine application only. By having his protagonists "playing God", as it were, Shakespeare adds layers of both tragedy and flaw to their characters while at the same time reinforcing the necessity of the boundaries they so foolishly transgressed. Through his use of interior and exterior spaces, physical objects, and metaphysical understandings of religion and the religious canon, Shakespeare distances the concept of resurrection from the more accepted Christian - specifically Protestant - meanings of redemption and rebirth, and redefines it through the use of what early modern Protestants would term witchcraft and black magic, forms of supernatural power associated with Catholicism against which the early modern English playgoer was vigorously indoctrinated. The characters of Friar Lawrence, Romeo, and Juliet, then, are placed in both physical and metaphysical danger as they overreach their strictly human abilities and attempt to access the powers of the divine. It is possible, Shakespeare shows us, that we can misuse deathscapes in terms of both the

5. Proverbs 16:18 states that "Pride goeth before destruction: and an hautie spirit before a fall", which was the defining characteristic Milton attributed to his character of Satan in Paradise Lost half a century later. While Renaissance theologians looked upon the idea of the Seven Deadly Sins with suspicion as a popish construction, the Renaissance age inherited the notion that pride is sinful from its medieval predecessors. 
dead and those who are seemingly brought back to life - and that tragedy ensues when we do so.

\section{Opposition in Resurrection, Landscape and Romeo and Juliet}

In opposition to Hans Urs von Balthasar's contention that in staging these moments of rebirth in his plays, Shakespeare "portray[s] the return from the realm of the dead as a pure gift to those in mourning $[\ldots]$ resurrection from the dead becomes the reappearance of those believed dead", ${ }^{6}$ I believe that Shakespeare had a much darker, more nihilistic view of the concept of resurrection in relation to his flawed protagonists. The moments of seeming resurrection for his tragic characters demonstrate the dangers and pitfalls that come from partaking of Satan's sin - in essence, being prideful enough to presume to possess God's powers. Shakespeare uses oppositional language and definitions to exemplify the boundaries between the two warring forces, and subsequently demonstrates the dangers of crossing those boundaries - in this case, the boundaries between the human and the divine. Friar Lawrence, for example, is the very embodiment of this dichotomy, and as a direct result of his inability to reconcile certain opposites - religion and magic, Protestant practices and Catholic ones, church and nature, even Capulet and Montague - he contributes to and even hastens Romeo and Juliet's tragic ends. As I will demonstrate, his misuse of the play's cultural deathscapes, and using his own power as a clergyman in culturally inappropriate ways, leads to the destruction of those people he holds most dear, leading us to believe that crossing such boundaries of landscape and morality causes irreparable physical and psychological harm to Shakespeare's tragic characters.

Shakespeare and his contemporaries tended to emphasize the importance of adhering to the culturally acceptable uses of sacred spaces, ${ }^{7}$ even

6. Hans Urs von Balthasar, Theo-Drama: Theological Dramatic Theory, 5 vols., vol. 1., trans. Graham Harrison (San Francisco: Ignatius Press, 1988), 384

7. Thomas J. J. Altizer differentiates "sacred space" from "quantitative space" in the early modern period in his article, "An Absolutely New Space", Literature $\mathcal{E}$ Theology (2007) 21:4, 347-61, 347. A "quantitative space" is one that "could only be understood mathematically and physically at once, an abstract space that is wholly other than the space of our common experience" while a sacred space as the Newtonian concept of "absolute space" that is "the realized space of God". Jeanne H. McCarthy makes the distinction between "sacred" and "secular" space in her article "The Sanctuarie is become a plaiers stage': Chapel Stagings and Tudor 'Secular' Drama", Medieval and Renaissance Drama in England (2008), 21, 56-86. when writing about deviation from Christian doctrine and the path of Christian morality. Marlowe's Faustus did, indeed, make a claim to Lucifer that he would "make my spirits pull [God's] churches down" (II.2.105), but he also promised

To [Lucifer] I'll build an altar and a church, And offer lukewarm blood of new-born babes! (II.1.14). ${ }^{8}$

Faustus is certainly transgressing the tenets of Christianity and reinforcing his place in the area of black magic, ${ }^{9}$ but he still acknowledges and advocates the proper use of sacred spaces; since he has no use for a church of God any longer, he promises to construct one for his new lord and master, and his vow of sacrifice demonstrates that he plans to use it in a manner completely appropriate for its scripted meaning. Like Friar Lawrence, Faustus transgresses early modern Christian morality; unlike Friar Lawrence, he keeps the cultural meanings of the landscape intact. John Webster also touches upon the accepted and acceptable uses of sacred spaces but, unlike Shakespeare, defines transgressions against them in terms of the monstrous. In The Duchess of Malfi he uses examples of desecrating such spaces as the epitome of evil and danger to the soul. Whilst discussing Ferdinand's troubling condition with Pescara, the Doctor defines for him the disease of "lycanthropia":

In those that are possess' $\mathrm{d}$ with't there o'erflows

Such melancholy humour, they imagine

Themselves to be transformed into wolves;

Steal forth to churchyards in the dead of night,

And dig dead bodies up: as two nights since

One met the Duke 'bout midnight in a lane

Behind St. Mark's Church, with the leg of a man

Upon his shoulder, and he howl'd fearfully;

Said he was a wolf, only the difference

Was, a wolf's skin was hairy on the outside,

His on the inside.

$\left(\right.$ V.2.6-18) ${ }^{10}$

In Webster's view, then, only those who are truly monsters, possessed, diseased, inhuman are capable of treating a sacred space, specifically one scripted as a deathscape, in such a culturally inap-

8. Christopher Marlowe, Dr. Faustus. The Norton Anthology of English Literature, ed. M. H. Abrams et al. (New York: W. W. Norton \& Co, 1993).

9. Thomas also makes the point that such Faustian legends "were extensively practiced, both by contemporary intellectuals and by less educated wouldbe magicians" during the Elizabethan era. Keith Thomas, Religion and the Decline of Magic: Studies in Popular Beliefs in Sixteenth and Seventeenth Century England (London: Weidenfeld and Nicolson, 1971), 230.

10. John Webster, "The Duchess of Malfi", The Norton Anthology of English Literature. 
propriate manner. The horror of this act is twofold; first, the lycanthropes dug up a "body" - not a skeleton. In the early modern period it was not uncommon to dig up skeletons and reposition bones in order to accommodate the newly dead, but this passage implies that the bodies were still a tad too fresh for such treatment. Secondly, it happened in a "churchyard", on consecrated ground, the implication being that had the lycanthropes dug up a heathen burial from an unconsecrated grave, the act would not have been considered as heinous. The act of desecration itself is offered up as a symptom of the disease, as if the two entities - inhuman monstrosity and the act of desecrating graves - are intimately connected. A normal human, it is implied - even one who is perhaps morally and tragically flawed, such as Friar Lawrence - would not participate in such culturally taboo behaviours.

In Shakespeare's works, however, it is much more likely that a seemingly well-meaning and particularly human character will neglect to adhere to the rules and regulations attendant upon a sacred deathscape, and that such an action carries with it dire consequences. This is true not only for Friar Lawrence in Romeo and Juliet, but in Shakespeare's comedies as well. Caliban, for example, perpetrates his nefarious actions upon the invaders of his land rather than on the land itself, as we learn when Prospero accuses him of seeking to "violate / The honour of my child" (The Tempest, I.2.349-50). ${ }^{11}$ However, Prospero himself is the one who has

[...] made shake, and by the spurs plucked up The pine and cedar; graves at my command Have waked their sleepers, oped, and let 'em [forth

By my so potent art.

(V.1.46-50)

The sympathetic protagonist, then, the man who has been wronged and who experiences the comedic resolution at the end of the play becomes the character who violates the scripted meaning of sacred spaces, in this case a graveyard. This leaves his actions open to accusations of necromancy "an ancient form of sorcery" that uses "magic with the aid of a dead person"12 - and black magic. The fact that Prospero "abjures" this magic and determines to leave his power behind when he departs the island indicates that Prospero implicitly understands the danger it would pose to him and his countrymen once he returns to Milan; such magic

11. All Shakespeare quotes are taken from William Shakespeare: The Complete Works, ed. Stanley Wells and Gary Taylor (Oxford: Clarendon Press, 2005).

12. Thomas, Religion and the Decline of Magic..., 230. would not fit into his restored life in Europe as the duke. One can imagine that such a prominent European centre of culture and art would require a much less primitive sort of magic, especially one that is "physical in its basis and effects" and "resides in props",13 which is the direct antithesis of the Protestant ideal of what religion and religious ritual should be.

Protestantism [...] presented itself as a deliberate attempt to take the magical elements out of religion, to eliminate the idea that the rituals of the Church had about them a mechanical efficacy, and to abandon the effort to endow physical objects with supernatural qualities. ${ }^{14}$

Therefore, Prospero's magic smacks much more of heretical Catholic practices with its fetishes and totems that contain and direct his power, and it makes sense that he would abandon such implements when returning to the "civilized" - or what the majority of early modern playgoers would define as "Protestant" - world. Shakespeare implies that Prospero's playing with magic and the objects of magic are dangerous, both to his person and his soul, but the magician demonstrates more understanding and communion with the landscapes than does Friar Lawrence, and shows wisdom in how he treats those spaces. ${ }^{15} \mathrm{He}$ recognizes their oppositional definitions and respects them whereas the Friar, as I will demonstrate, portrays a bewildering ignorance of the meanings attendant on his environment. Both Shakespeare's characters mirror the human condition of inner conflict and the duality between good and evil - or, to be less abstract, the dichotomy between people's knowledge that we should make good decisions and our penchant for making bad ones ${ }^{16}$ - that all human-

13. Margreta de Grazia, "The Tempest: Gratuitous Movement or Action without Kibes and Pinches", Shakespeare Studies 14 (1981), 249-65, 255.

14. Thomas, Religion and the Decline of Magic..., 76.

15. Interestingly, James Kearney notes: “Certainly, theatrical productions can and have staged Prospero's book or books, but the printed text suggests that The Tempest consists of plots and characters that revolve around an archive that is always elsewhere, always off stage." This would seem to support the idea that interacting with or viewing such objects is in some way dangerous or abhorrent, even when representing a predominantly Catholic nationality (Italy) on stage, but to a predominantly Protestant audience. James Kearney, "The Book and the Fetish: The Materiality of Prospero's Text", Journal of Medieval and Early Modern Studies 32:3 (2002), 433-68, 434

16. Susan Snyder has pointed out that Romeo and Juliet has no clearly defined archetypal protagonists: "There is no villain, only chance and bad timing". Susan Snyder, The Comic Matrix of Shakespeare's Tragedies (Princeton: 
kind recognizes and experiences. However, Friar Lawrence's attempt to actually be two conflicting things at the same time - good and evil (though perhaps "moral" and "heretical" would be more appropriate terms), human and divine - rather than choosing one clear trait to define his character ultimately results in epic failure and tragedy, a fate that Prospero happily escapes. It is as if Shakespeare sets out to prove the scientific principle that no two objects can physically occupy the same space at the same time, only in a metaphysical sense; a person cannot be both fish and fowl simultaneously. Shakespeare's spaces must also adhere to the same principle - a landscape cannot be both a resting place for the dead and a site of resurrection outside the circumference of religious doctrine. When deathscapes as sacred spaces are desecrated this way, they retaliate in an attempt to restore the balance of nature and a return to the culturally acceptable norm.

Romeo and Juliet is one such play of extreme oppositions of both character and space, and Shakespeare displays many examples throughout of how contrary forces inhabiting the same character wreak destructive havoc. Upon learning Romeo's family name, for example, Juliet laments that "My only love sprung from my only hate!" (I.5.137). John Cox examines this paradox as proof of Juliet's strength of character: "her love overcomes her inherited hatred, and she risks committing herself to a Montague, defying her father in the process and concealing her commitment" ${ }^{17}$ However, it is also fruitful to look at this juxtaposition of opposites in light of the play's outcome, and it becomes clear that despite her struggles to synthesize these opposing forces, they ultimately contribute to her destruction. Her ability to recognize this duality is obviously no safeguard against the damage that it can do. Romeo, too, builds his love for Juliet upon a paradox of oppositional feelings, and he also recognizes the problem inherent in the relationship between the two:

Princeton University Press, 1979), 66. She in fact echoes Dr. Samuel Johnson's complaint about Shakespeare in general, that he "makes no just distributions of good or evil, nor is always careful to shew in the virtuous a disapprobation of the wicked; he carries his persons indifferently through right and wrong, and at the close dismisses them without further care, and leaves their examples to operate by chance. This fault the barbarity of his age cannot extenuate; for it is always a writer's duty to make the world better, and justice is a virtue independent on time or place". Samuel Johnson, Dr. Johnson on Shakespeare, ed. W. K. Wimsatt (London: Penguin Shakespeare Library, 1969), 211.

17. John Cox, Seeming Knowledge: Shakespeare and Skeptical Faith (Waco, Texas: Baylor University Press, 2007), 72.
Here's much to do with hate, but more with love.

Why, then, O brawling love! O loving hate!

$\mathrm{O}$ any thing, of nothing first create!

O heavy lightness! serious vanity!

Mis-shapen chaos of well-seeming forms!

Feather of lead, bright smoke, cold fire, sick

[health!

Still-waking sleep, that is not what it is!

This love feel I, that feel no love in this.

(I.1.171-78)

Romeo's prodigious use of oxymoron serves to illuminate his feelings of confusion and disorientation regarding love and how it affects him, but it also demonstrates Romeo's role as a vessel forced to contain - at least temporarily - opposing forces at war with each other. ${ }^{18}$ Romeo himself becomes a victim of this conflict, and his death demonstrates his inability to reconcile his disparate natures. Juliet recognizes this schism between fair and foul in Romeo when she laments, "Was ever book containing such vile matter / So fairly bound?" (III.2.83-84), yet once again the ability to recognize the division does not offer immunity from its dangers. The feud between the Montagues and the Capulets, represented by the two title characters, becomes a microcosmic mimesis of the larger problem of opposition in the play that which exists between Catholic practices and Protestant doctrine. This is reinforced by the fact that Juliet defines Romeo as a "book" that looks fair but can be read as foul - he is like the Bible, which was used in Catholic rituals but has been "rebound" for Protestant use.

\section{Catholic Magic and Protestant Scepticism}

Friar Lawrence embodies this schism possibly better than any other character in Romeo and $\mathrm{Ju}$ liet, both in his profession and in the actions he takes while using the powers granted to him by that profession - specifically in his dealings with landscape and the natural world. The very first words he speaks in the play introduce him as a

18. Hunter and Lichtenfels attribute these oxymorons to a Galenic vision of the humours that suggest that Romeo's emotional unpredictability and his seemingly unnaturally feminized actions and reactions to love stem from an imbalance of his bodily chemistry, and that Juliet's "own skill with words and rhetoric would mark her out, in Elizabethan society, as having masculine traits", so it would appear that both Romeo and Juliet also embody within them both the masculine and the feminine, which could contribute to their relative destructions. Again it is demonstrated that opposites cannot occupy the same human space without harm. Lynette Hunter and Peter Lichtenfels, Negotiating Shakespeare's Language in "Romeo and Juliet": Reading Strategies from Criticism, Editing, and the Theatre (Farnham: Ashgate, 2009), 134, 137. 
character who speaks and thinks with opposites, for he proclaims that

The grey-eyed morn smiles on the frowning [night,

Chequ'ring the eastern clouds with streaks of

[light.

Morning and night, east and west, cloudy and sunny, smiles and frowns: Friar Lawrence packs a great many opposites into the first two lines of poetry he utters on the stage. As audience members, we should not be surprised, then, when it becomes clear that one of Friar Lawrence's main functions in this play is to negotiate the boundaries between oppositional forces, both physical and metaphorical.

Perhaps the most important boundary that he crosses is the one between religion and magic. Our first introduction to Friar Lawrence, the very person who incidentally devises the resurrection plot in the play, has him expounding upon the nature of a plant he is examining:

Within the infant rind of this weak flower Poison hath residence, and medicine power, For this, being smelt, with that part cheers each [part;

Being tasted, slays all senses with the heart. Two such opposed kings encamp them still In man as well as herbs - grace and rude will; And where the worser is predominant, Full soon the canker death eats up that plant. (II.2.23-30)

Friar Lawrence defines the plant in much the same way we have seen Romeo and Juliet themselves defined - through a duality of nature. The plant is both a "poison" and a "medicine"; it can "slay" and it can "cheer" parts of the body; it has "grace" and "rude will" at the same time. His description of these conflicting characteristics as "opposed kings" reinforces the contrariety of its nature, as well as the dangers implicit in that duality. Such wars have victims, and fallen soldiers - in this case, Romeo and Juliet themselves - pay the price of the clash. Robert Grudin claims that "Lawrence's doctrine of medicine, nature, and psychology is conspicuously Paracelsian" in this passage, in that he echoes Paracelsus" "idea of the interdependency of life and death". ${ }^{19}$ Indeed, Friar Lawrence's musings fourteen lines earlier that

The earth, that's nature's mother, is her tomb. What is her burying grave, that is her womb (II.2.9-10)

19. Robert Grudin, Mighty Opposites: Shakespeare and Renaissance Contrariety (Berkeley: University of California Press, 1979), 36. seems to echo Paracelsus' claim that "[...] death followeth life, and of death, life riseth".$^{20}$ Ideally, both Paracelsus and Friar Lawrence refer to the natural cycle of life in which life and death are dependent upon each other; however, in light of the resurrection plot that the Friar devises and the tragic events that occur as a result, I would argue that the Friar's fascination with the plant demonstrates the existence of two completely incompatible (to a Protestant audience) natures extant within him - the one defining him as a priest and the other scripting him as a magician. Therefore, rather than arguing that Shakespeare adheres to the overtly Christianized perceptions and representations of resurrection as other critics have done, ${ }^{21}$ or going too far in the opposite direction and claim that "Shakespeare's genius is too impersonal to sustain a religious meaning", 22 I believe that he dips into his knowledge of pagan ritual and religion and imposes into his representations of resurrection elements of black magic, ${ }^{23}$ or what Keith Thomas terms

that kind of witchcraft which contemporaries thought harmful or anti-social. It cannot be clearly distinguished from other sorts, since, as has been seen, many clergy taught that magic, whatever its objective, was reprehensible. At a popular level every kind of magical activity, including any unacceptable brand of religion, might be lumped together under the blanket title of "witchcraft". ${ }^{24}$

Shakespeare distances these moments from the Christian "sacralization" of resurrection and simultaneously emphasizes the scepticism and mistrust that existed towards the concept of miracle of any sort in the early modern period, for these critics seem to be neglecting to account for the fact that even the biblical representation of resurrection has its dark side. Stephen Greenblatt acknowledges this scepticism in Shakespeare even while assert-

20. Grudin, Mighty Opposites..., 36.

21. See my previous statement regarding Hans Urs von Balthasar.

22. David Gervais, "Tragic Endings", PN Review. 35:4 (2009), 19-26, 23.

23. For other discussions of magic in Renaissance literature and Shakespeare, see John Mebane's Renaissance Magic and the Return of the Golden Age: the Occult Tradition and Marlowe, Jonson, and Shakespeare (Lincoln: University of Nebraska Press, 1989), Thomas Jones' Renaissance Magic and Hermeticism in the Shakespeare Sonnets (Lewiston, N.Y.: Edwin Mellen Press, 1995), and Ryan Curtis Friesen's Supernatural Fiction in Early Modern Drama and Culture (Eastbourne: Sussex Academic Press, 2010).

24. Thomas, Religion and the Decline of Magic..., 435-36. 
ing that it is absent - or at least subsumed - in Shakespeare's plays:

Shakespeare began his life with questions about his faith, his love and his social role. He had never found anything equivalent to the faith on which some of his contemporaries had staked their lives. If he himself had once been drawn toward such a commitment, he had turned away from it many years before. To be sure, he had infused his theatrical vision with the vital remnants of that faith. ${ }^{25}$

I would argue that Shakespeare was more overt regarding his scepticism in his plays than Greenblatt here suggests, especially concerning his representations of resurrection and the spaces in which they take place. ${ }^{26}$

The word "resurrection" is a somewhat loaded term in the early modern period. The word itself evokes what Sean Benson terms "biblical tropes or figurations"; $; 7$ that is, the word lends itself to a primarily Christian reading. Benson claims that in his plays, Shakespeare "repeatedly evokes Christ's resurrection from the dead when longlost characters reunite; at those moments, he subtly superimposes the Resurrection on his 'recognition scenes'" ${ }^{28}$ Therefore Benson, like Hans Urs von Balthasar, views the concept of resurrection in Shakespeare through a narrowly focused positive and Christianized light, claiming that "connected to biblical conventions, the ritual of recognition lends itself readily to the idea of resurrection". ${ }^{29}$ He makes the association between "resurrection" and "recognition" because "[none] of the characters [are] literally resurrected from the dead" ${ }^{\prime \prime 0}$ and

25. Stephen Greenblatt, Will in the World: How Shakespeare Became Shakespeare (New York: W. W. Norton \& Co., 2004), 388

26. For more criticism regarding scepticism in Shakespeare, see Graham Bradshaw, Shakespeare's Scepticism (Ithaca: Cornell University Press, 1991), Millicent Bell, Shakespeare's Tragic Skepticism (New Haven: Yale University Press, 2002), William M. Hamlin, Tragedy and Scepticism in Shakespeare's England (New York: Palgrave Macmillan, 2005), Anita Gilman Sherman, Skepticism and Memory in Shakespeare and Donne (New York: Palgrave Macmillan, 2007), and John D. Cox, Seeming Knowledge: Shakespeare and Skeptical Faith (Waco: Baylor University Press, 2007).

27. Sean Benson, Shakespearean Resurrection: The Art of Almost Raising the Dead (Pittsburgh: Duquesne University Press, 2009), 2.

28. Benson, Shakespearean Resurrection..., 1.

29. Benson, Shakespearean Resurrection..., 56.

30. Benson, Shakespearean Resurrection..., 57. that the resultant "quasi resurrections" ${ }^{31}$ represent a parallel to the singularly redemptive Christian idea of the miracle of Resurrection.

Benson, therefore, situates Shakespeare's visions of resurrection through the lens of Christian allegory only and as such he views the "recognition" of reunion as solely positive. While he makes the point that "Resurrections are not exclusive to the Christian tradition", he emphasizes that "Shakespeare's use of such figurations draws almost exclusively on the Christian understanding of resurrection and on Christ's resurrection itself". ${ }^{32}$ Resurrection, in this light, as a miracle of rebirth and reunion, remains a source of wonder and resolution and does not, Benson claims, in any way "desacralize the Christian understanding of resurrection". ${ }^{33}$ Cynthia Marshall identifies resurrection as one of the key elements in Shakespeare's later plays: "An inherent motif in each of Shakespeare's last plays is afterlife-or its corollary in the theatre, the return of the dead" ${ }^{34}$ Since "resurrection-plots often follow the precise outlines of Christian myth" in the Renaissance, ${ }^{35}$ it follows that the myth is staged with a desire to evoke a shared cultural sense of emotion and wonderment, and to reinforce the central foundations of religion in the midst of tumultuous change. For example, in Laurence Twine's prose work The Patterne of Painefull Adventures (1594), which was a translation from John Gower's Confessio Amantis and served as a source for Shakespeare's play Pericles, the character Apollonius of Tyrus experiences a joyful reunion with his wife: she had, he thought, died in childbirth, after which he had

[...] laid her into the chest, and [...] placed a great summe of golde at her head, and a great treasure of siluer at her feete [...] then closing up verie safe, commanded the chest to be lifted ouerboard into the sea. ${ }^{36}$

31. Benson, Shakespearean Resurrection..., 2.

32. Benson, Shakespearean Resurrection..., 16-17, 187. The only exception, Benson claims, are the "mock resurrections" of Falstaff and Cleopatra, in which he claims "[t]he evocation of the Resurrection is only lightly if at all evident", though he terms such "mock resurrections" as "variations on Shakespeare's quasi resurrection".

33. Benson, Shakespearean Resurrection ..., 96.

34. Cynthia Marshall, Last Things and Last Plays: Shakespearean Eschatology (Carbondale: Southern Illinois University Press, 1991), xiv.

35. Jacob Israel Littleton, Resurrection Doctrine and the Plot of False Death in English Renaissance Drama, Ph.D. dissertation (University of California, Los Angeles, 2005), 3.

36. Laurence Twine, The Patterne of Painefull Adventures (London: Nathaniel Butter, 1594), $\mathrm{Di}^{\mathrm{r}}$. Accessed from the 
Her reappearance into his life, therefore, reads to him like a true resurrection, that is, as a return from the dead, and he expresses suitable gratitude to He who enacted the seeming miracle:

Blessed be the moste mightie God of heaven, which doth sitte aboue, and beholdeth the state of men on earth, and dealeth with them according to his great mercie: who nowe also of his unspeakable goodnesse, hath restored unto mee my wife and my daughter. ${ }^{37}$

Sean Benson, in discussing this passage, makes the comment that Twine's dealings with resurrection here are "almost comically Christianized" and cites Shakespeare's subversion of the Christian elements in his play Pericles as a "call for a descent into figurative death that is in reality a restored life". ${ }^{38}$ Shakespeare takes this "figurative death" to a rather humorous degree; when Pericles is reunited with Thaisa at the end of Pericles his wife actually re-enacts her own false death and resurrection again. Upon seeing him, she exclaims, "Voice and favour - / You are, you are - O royal Pericles!" (22.34-35) and then she faints. Pericles, all astonishment at this turn of events, cries, "What means the nun? she dies! help, gentlemen!" (22.35), once again revisiting the sense of loss that her death had upon him the first time. However, upon her second "resurrection", her recovery from the faint, Pericles is convinced of the reality of her presence and states,

This, this: no more, you gods! your present [kindness

Makes my past miseries sports: you shall do [well,

That on the touching of her lips I may

Melt and no more be seen. $\mathrm{O}$, come, be buried

A second time within these arms.

$(22.62-66)$

His words, however, lack the Christianized ideal of redemption rooted in Apollonius' words and hint at a scepticism that such an ideal is possible.

Apollonius spoke of redemption and life renewed; Pericles, on the other hand, speaks of yet another form of death. He claims that a touch of his wife's lips would make him "melt and no more be seen", and invites her to die and "be buried" once again, this time alongside him as husband and wife. ${ }^{39}$ Shakespeare on one level puns on the

Bodleian Library via EEBO on August 25, 2010.

37. Twine, The Patterne of Painefull Adventures, Kivv.

38. Benson, Shakespearean Resurrection..., 134.

39. This is also reminiscent of a moment in Hamlet, which Shakespeare had written some eight years earlier, when Laertes leaps into Ophelia's grave and demands sexualized meaning of "death" and indicating a sexual desire for Pericles and his wife to "die" together - that is, experience orgasm - while on another he subverts the culturally acceptable meaning of the deathscape by suggesting a sexual act inside a grave. This in itself further distances the passage from a Christianized representation of resurrection. The fact that Thaisa moves so quickly from "nun" to an object of sexual desire in her husband's mind also demonstrates this distance, and offers the audience yet another form of opposition and religious subversion. It is these moments of transgression against both religious doctrine and deathscapes, it seems, that Shakespeare wants us to experience in Romeo and Juliet, and he is less interested in the redemptive value of resurrection than with its performative value as a measure of emotional attachment reminiscent of pagan rituals. By distancing resurrection from its Christian meaning in the play, Shakespeare casts a shadow of scepticism upon the act and performance of resurrection itself.

This scepticism has its roots partly in the Bible stories in which moments of resurrection occur; Christian doctrine tells of several instances of "true resurrection" in the Bible - that is, literally transforming a person from fully dead to fully alive after a passage of time through the use of miracle. One such story is Jesus Christ's own resurrection celebrated through the rituals of Easter and described in all four Gospels, each one emphasizing not just the reunion and redemption of Christ's death and rebirth, but also the doubt that the miracle itself produces in the populace. Matthew 28:16-17 states that "Then the eleuen disciples went away into Galilee, into a mountaine where lesus had appointed them. And when they saw him, they worshipped him: but some doubted". Mark 16:9-11 claims that

Now when Iesus was risen early, the first day of the weeke, he appeared first to Mary Magdalene, out of whom he had cast seuen deuils. And she went and told them that had beene with him, as they mourned and wept. And they, when they had heard that he was aliue, and had beene seene of her, beleeued not.

that the gravedigger "pile your dust upon the quick and the dead, / Till of this a flat mountain you have made" (V.1.247-48). The fact that Laertes enters the grave and emerges from it alive represents a symbolic form of resurrection that ends in a true death rather than reunion or redemption. These moments, paired with invocations to pagan gods and goddesses and defined as utterly taboo in the Judeo-Christian tradition, further remove such actions from a Christianized reading of the meaning of death and resurrection. 
Luke 24:10-11 writes it as,

It was Marie Magdalene, \& Ioanna, \& Mary the mother of Iames, and other women that were with them, which tolde these things vnto the Apostles. And their words seemed to them as idle tales, and they beleeued them not,

while John 20:14 states that Mary Magdalene entered the sepulchre and "turned herselfe backe, and saw lesus standing, and knew not that it was Iesus". In all the Gospels, doubt and scepticism play a significant role in the spectacle of resurrection, in a large part due to the cultural expectations regarding the deathscape and space upon which it takes place. ${ }^{40}$ When entering a tomb or a sepulchre, we are comfortable with seeing a dead body there - at least, much more so than in a landscape not specifically scripted for use of and for the dead. However, as demonstrated through these Gospels, not seeing an expected corpse in such a venue causes just as much anxiety, because the situation does not fit with the cultural meaning of the examined space.

Perhaps this is one of the reasons why Shakespeare seems disinclined to portray resurrection without an inherent sense of distance and tragedy. Sean Benson has previously noted that Shakespeare has a tendency to transform biblical language and intent from its original meaning and context:

The thousands of [biblical] passages [...] demonstrate Shakespeare's easy familiarity with the Bible, The Book of Common Prayer, and other ecclesiastical language, some of which appears

40. Another such tale that demonstrates the anxiety and cultural struggle with the concept of resurrection is the story of Lazarus of Bethany from the Gospel of John. In the story, Jesus hears of Lazarus' sickness and waits for two days before heading to Bethany to speak with his sisters, Mary and Martha. He knows that Lazarus will die in those days, and plans to use the miracle of resurrection to, as he says to his Father, demonstrate proof to the people "that they may beleeue that thou hast sent me" (John 11:42). Indeed, many of the onlookers are struck with wonder and "beleued on" (John 11:45) Jesus after his performance of the miracle of resurrection, but others had some reservations and concerns: "But some of them went their wayes to the Pharises, and tolde them what things Iesus had done. Then gathered ye chiefe Priests and the Pharises a councell, and said, What doe wee? for this man doeth many miracles. If we let him thus alone, all men will beleeue on him, and the Romanes shall come, and take away both our place and nation." (John 11:46-48) It was this action of raising the dead back to life that caused the Pharisees to decide that "from that day foorth they tooke counsell together for to put him to death" (John 11:53), for the fact that a man had the power to perform miracles made him a grave danger to those in power. verbatim in the plays. Most of Shakespeare's borrowings, however, merely resonate with their sources, having undergone change in transmission from source to stage. ${ }^{41}$

Because of this, I find it significant that the word "resurrection" in any of its iterations appears only once in all of Shakespeare's works. ${ }^{42}$ Despite Benson's assertion that "figurations of resurrection exist in 14 of the plays, a surprisingly high number", ${ }^{\prime 3}$ it would appear that images of resurrection in the true Christian sense - that is, coupled with a sense of renewal, salvation, and hope - are scarce, if not entirely absent in his plays, especially when we consider that the moments in Shakespeare of seeming resurrection or rebirth are invariably paired with a hefty price. Shakespeare may have wished to preserve the biblical invocation of doubt and a lack of faith in Christ's ability to be both human and divine demonstrated in the gospels, but he does not give the opposite representations of hope and wonder equal billing, which is perhaps why he chooses not to invoke the word in his plays.

Keith Thomas tells us that one of the fundamental struggles between religion and magic lies in the definition and meaning of space and landscape. During the Protestant Reformation, he claims, there was a distinct removal of religion from the natural world, for "Satan, it was believed, was well acquainted with the secrets of nature and might counterfeit an effect when he could not reproduce it directly". ${ }^{44}$ Presumably, this is why it was commonly believed that covens congregated outside in forests and natural environments, despite the fact that "Accused witches had no demonstrable links with a pagan past. If any of them served the Devil, it was only too obviously the same Devil as that portrayed by the conventional religious

41. Benson, Shakespearean Resurrection..., 159.

42. Sir Hugh Evans in The Merry Wives of Windsor speaks the word in his speech: "It is that fery person for all the world, as just as you will desire; and seven hundred pounds of moneys, and gold and silver, is her grandsire upon his death's-bed - Got deliver to a joyful resurrections! - give, when she is able to overtake seventeen years old". (I.1.46-51). It is perhaps indicative of Shakespeare's troubled relationship with the concept of resurrection that he has the word spoken by a Welshman whose speech is the object of ridicule and misunderstanding by the rest of the characters. Incidentally, the word "rebirth" does not appear at all in any of Shakespeare's works.

43. Benson, Shakespearean Resurrection..., 2.

44. Thomas, Religion and the Decline of Magic..., 256. 
teaching of the day". ${ }^{45}$ Faustus, after all, made a point of asking his teachers to

[...] shew me some demonstrations magical,

That I may conjure in some lusty grove,

And have these joys in full possession.

(I.1.152-54)

The literal church building, then, served to physically and spatially distance God-fearing churchgoers from the perceptions of such practitioners of magic, which is one reason the early modern clergy was so intent upon excising Catholic practices, iconography, and materialism from the physical spaces of churches themselves. Doreen Rosman notes that "Elizabethan homilies had challenged the old Catholic belief in holy places, maintaining that churches were holy only because 'gods people resortynge thereunto are holy and exercise themselves in holy and heavenly thynges ${ }^{\prime \prime},{ }^{46}$ which not only distanced the physical space from the taint of Catholic practices but also allowed for multiple meanings to inhabit that space. In both the built environment and the natural landscape, it is understood that spaces may of course be layered with multiple meanings, and sacred spaces are no exception. As far back as the early Middle Ages, "[s]ecular authorities used ecclesiastical buildings and lands for non-religious or only partly religious purposes" because such spaces "were not always considered a completely different world, but were often seen as part of the space where more secular activities and events were commonplace" ${ }^{47}$ In the late Middle Ages, "[t]he secular use of mendicant convents [...] was not unusual" and such sacred spaces were often "used to store records or to serve as a venue for political and diplomatic negotiations" ${ }^{48}$ Seemingly oppositional meanings can, indeed, inhabit the same space - as long as those meanings are clearly defined and adhere to the tenets created for them. A church, for example, may be the scene for both baptisms and funerals, rituals of birth and death, celebration and mourning - but there are strict doctrinal rules and social mores that determine how these spaces are to function. There are, to put it simply, boundaries that must be respected and adhered to. This is why a church has both a baptismal font and a crypt,

45. Thomas, Religion and the Decline of Magic..., 525.

46. Doreen Rosman, The Evolution of the English Churches: 1500-2000 (Cambridge: Cambridge University Press, 2003), 75.

47. Paul Trio and Marjan de Smet, eds., "Introduction", The Use and Abuse of Sacred Places in Late Medieval Towns (Leuven, Belgium: Leuven University Press, 2006), vii.

48. Jens Röhrkasten, "Secular Uses of the Mendicant Priories of Medieval London", The Use and Abuse of Sacred Places in Late Medieval Towns. and why there are distinct rules and guidelines regarding the use of each space. ${ }^{49}$

\section{"I'll to the friar, to know his remedy [... ]"}

When Friar Lawrence steps out on stage and soliloquizes on the mysterious properties of a plant, he calls the boundary between those distinct rules into question, presenting an object from the natural world to an audience that has vehemently rejected nature as a source of divine power and magic. Again, two opposing forces unsuccessfully attempt to occupy the same space because the Friar is actively transgressing those protective boundaries. Suddenly, the Friar is thrown into a suspicious light in the early modern mindset as the audience is asked to accept his very Catholic fascination with the trappings of nature - a perception of evil in the form of a clergyman, whose very role should be to lead his flock away from the Devil. This suspicion is later justified by the plan he devises to reunite Romeo and Juliet and the potion he employs to do so. He offers the "distilled liquor" as a solution to the lovers' problem and tells Juliet that upon drinking it,
[...] presently through all thy veins shall run A cold and drowsy humour; for no pulse Shall keep his native progress, but surcease. No warmth, no breath shall testify thou livest. The roses in thy lips and cheeks shall fade To wanny ashes, thy eyes' windows fall Like death when he shuts up the day of life. Each part, deprived of supple government, Shall, stiff and stark and cold, appear like death... (IV.2.94-103)

The potion is clearly created from a natural element, since it has been "distilled" into a liquid form, and Friar Lawrence's description of the elixir exactly mirrors Thomas' analysis of the early modern desire and reasoning for excluding nature from Christianity. By Thomas's reckoning, then, the Friar becomes like the Devil, for he is "acquainted with the secrets of nature" and the potion itself can "counterfeit an effect" that Friar Lawrence cannot reproduce directly - resurrec-

49. As Francis Bond states in his book An Introduction to English Church Architecture: From the Eleventh to the Sixteenth Century, "planning is the expression of purpose" and therefore the architects who built the churches and cathedrals needed "first to be set forth the requirements [...] of the various classes of church which were in use". Ecclesiastical buildings were constructed with very specific purposes in mind, and each part had its own sets of specific measurements, placement, direction, size, configuration, etc. Francis Bond, An Introduction to English Church Architecture: From the Eleventh to the Sixteenth Century (Oxford: Oxford UP, 1913), 29. 
tion. The Friar turns to the potion rather than to God for help, and Romeo and Juliet end up paying the price for his pride in thinking that his black magic can replace the need for God. The plant, then, is a representation of the Friar's most significant flaw, and so it comes as no surprise that even though it succeeds in its "divine" purpose, it cannot save the lovers from their human faults. I find it significant that not once during his speech to Juliet does Friar Lawrence invoke or acknowledge the name of God, either as the true power behind the potion or as a protector from its perils. As a deus ex machina, the plant and the potion fall far short of actual divine intervention. It is a false god, and as such cannot deliver on the Friar's promise of a new life "free [...] from this present shame" (IV.2.118). The Friar himself becomes guilty of worshipping a false god, much as he is guilty of abusing the sacred space of the true God he has sworn to serve. Juliet reveals her mistrust of his sinful and misguided nature when she actually fears that Friar Lawrence is attempting to kill her with the elixir:

What if it be a poison, which the friar Subtly hath minister'd to have me dead Lest in this marriage he should be dishonoured. $(\text { IV.3.23-25) })^{50}$

What if, she muses, he created the potion from the plant he was examining at the beginning of the play that "Being tasted, slays all sense with the heart" (II.2.26)? He is the snake, the potion is the apple, and Juliet becomes Eve, tempted into sin.

The churchyard and the tomb, and the way their meanings are challenged and disrupted in this play, have significant roles in the Friar's plan for a false resurrection as well. It is clear that Friar Lawrence knows full well the proper significations of the sacred spaces in the play. When he comes upon the evidence of Romeo's violent fight with Paris at the entrance to the Capulet's tomb, he exclaims,

Alack, alack, what blood is this which stains The stony entrance of this sepulchre?

What mean these masterless and gory swords To lie discoloured by this place of peace?

(V.3.140-43)

He is not only alarmed by the sight of blood and violence itself, but by its proximity to the tomb

50. It is possible that Juliet here is revealing a common early modern association between Catholicism and poison, especially considering that the play takes place in Italy. The Borgias, well-known Catholics, were also very famous poisoners - so much so that the association between poisoning and Catholicism made its way into many early modern dramas. where the dead are placed for their eternal rest. His injunction to Juliet that she shall

... be borne to that same ancient vault Where all the kindred of the Capulets lie" (IV.1.111-12)

also demonstrates his understanding of one of the primary functions of the church landscape. According to Paul Trio, "[o]f special importance was the right to asylum, which allowed criminals or persons who were being persecuted to escape the judicial power of the urban or central authorities",, 1 and there can be no doubt that Friar Lawrence attempted to help Juliet in this respect. Her father's heated insistence that she marry Paris, and his use of threats of abandonment, ${ }^{52}$ physical violence ${ }^{53}$ and emotional blackmail ${ }^{54}$ to force her to adhere to his demands certainly paint a picture of persecution by an authority figure over a subject powerless to resist on her own. As we are well aware, however, Lawrence's offer of "asylum" from her choice of a bigamous marriage or abandonment and bodily danger had the opposite effect and succeeded only in putting her in graver danger, and the accepted and traditional function of the tomb asserts itself as a grisly reminder to respect and remember the culturally scripted meanings of sacred spaces - death wins out over resurrection. ${ }^{55}$ Because he in his pride forgot that

51. Trio, "Introduction", The Use and Abuse of Sacred Places in Late Medieval Towns, xi.

52. "I'll give you to my friend; / And you be not, hang, beg, starve, die in the streets." (III.5.191-92).

53. "Speak not, reply not, do not answer me; / My fingers itch" (III.5.162-63).

54. "Wife, we scarce thought us blest / That God had lent us but this only child; / But now I see this one is one too much" (III.5.164-66).

55. For the purposes of this discussion, I define the space in which Romeo and Juliet dispatch themselves as an interior space connected by shared meaning to the larger structure of the church itself. While it is true that much of the action of Act $\mathrm{V}$ takes place in the church or graveyard as an exterior setting, Friar Lawrence's description of Juliet's deathspace as a "vault" and a "monument" denotes an interior and enclosed space. Jennifer A. Low describes the probable staging of the scene in a way that supports this reading as well: "Produced by the Lord Chamberlain's Men [...] Romeo and Juliet was performed on the public stage. The tomb to which the stage directions refer several times would, logically, have been represented by the tiringhouse, receding from the façade at the back of the large platform stage. Audiences might even have had to squint or lean forward to see Juliet's exact gesture in that shadowy recess. Aside from the prone bodies of Romeo on the inside and Paris on the threshold, Juliet 
the church and its environs were God's house and neglected to include the deity in his plans, and because he attempted to circumvent the meaning of the space, Friar Lawrence's well-meaning but illconceived plan fails.

Lawrence actually falls short of his ecclesiastical duties regarding the sacred spaces of which he was supposedly the custodian on a number of levels, and his last-ditch attempt to use the crypt as a site of staged resurrection is only the final albeit the most egregious - example of his pride. First, Lawrence urges Juliet to agree to marry Paris when he knows she is already married to Romeo:

Hold, then; go home, be merry, consent To marry Paris.

(IV.1.89-90)

Not only does he urge his young parishioner to tell a falsehood, but he counsels her to agree to, at least on the surface, a bigamous marriage. Bernard Capp explains that, "In the sixteenth century, as earlier, bigamy was merely a spiritual offence, prosecuted in the church courts. That changed in 1604, when parliament made it a felony"..$^{56}$ Since Romeo and Juliet was first performed in 1594, that would make Friar Lawrence's advice more perilous for Juliet's immortal soul than for her earthly body. The fact that Lawrence subsequently arranges this form of sanctuary is no safeguard for her soul, since he does so in order to perpetuate the sin rather than repent of it. Lawrence uses the tomb as a means to an end and does not respect its rightful meaning. As such, the landscape turns against Friar Lawrence and disrupts the resurrection and reunion; he can sense his own doom from signs and signals from the very deathscape he is supposed to tend:

would have been quite alone as she stabbed herself [...] Both stagings enclose the death scene." However, Friar Lawrence spends most of the remaining play outdoors in the churchyard, which demonstrates that he aligns himself more with the wilderness of nature, that place where Balthasar slept "under this yew tree here" (V.3.137) rather than with the enclosed interior space specifically built to house the dead. Jennifer A. Low, "'Bodied Forth': Spectator, Stage, and Actor in the Early Modern Theater", Comparative Drama 39:1 (Spring 2005), 1-29, 2.

56. Bernard Capp, "Bigamous Marriage in Early Modern England", The Historical Journal 52:3 (2009), 537-56, 539 .
How oft tonight

Have my old feet stumbled at graves?

(V.3.121-22),

he muses to himself, surprised that such familiar ground would trip him up so often that night. He is at odds not only with his duties as a clergyman, but with the very landscape he has been charged to oversee, and it stays his steps and impedes his path so that he is unable to get to Romeo in time to tell him the truth about Juliet's condition and the plan he had concocted. Had he not stumbled so often, it is implied, he may have been in time to prevent Romeo from drinking the poison, thereby salvaging the plan and saving both lovers' lives. The landscape itself rears up to dispense justice upon the characters for their sins of pride, for had the plan succeeded, all three would have enjoyed a happy reward that by Christian doctrine they did not deserve. Their transgressions of accepted boundaries, however, made that outcome impossible.

The Catholic elements of Shakespeare's plays are much discussed and analyzed, posited and theorized in literary criticism, and there are those who reject for him the label of "Catholic" and those who see in his work its potential. However, I am less interested in what religion Shakespeare himself might have been than in how he uses Catholic elements as a vehicle to portray the importance of Protestant ideals, and what happens when the boundaries between the two are transgressed. His use of Protestant scepticism of Catholic practices serves to insist on the importance of those boundaries, and the way he positions his characters upon the landscapes of the dead demonstrates a deep understanding of their cultural meanings, and an almost unholy glee in violating them. Friar Lawrence's transgressions in his attempt to enact a false resurrection upon Juliet results in the most stark and shattering oppositional relationship of all in the play, for he fails to bring forth renewed life and becomes complicit in murder and death instead. Crossing those boundaries results in ruination of both the physical and the spiritual self, for Friar Lawrence should have known that attempting to play God would only turn his deity against him in the end.

Sharon EMMERICHS 